\title{
Hubungan Motivasi Belajar dan Optimisme Masa Depan dengan Prestasi Belajar Mata Pelajaran Bahasa Inggris Di Kesehatan SMKN 9 Kota Tangerang
}

Ary Nurmalasari ${ }^{1}$, Rizki Isfahani ${ }^{2}$

STIKes YATSI Tangerang, Tangerang, Indonesia arynurmala27@gmail.com ${ }^{1}$, rizki_isfahani@yahoo.co.id ${ }^{2}$

\section{Keywords :}

Motivasi belajar, optimisme masa depan, prestasi belajar

\begin{abstract}
Motivasi belajar pada siswa SMKN 9 Kota Tangerang dengan 40 siswa menyatakan bahwa (62,5\%) siswa kesulitan belajar bahasa inggris dan (55\%) siswa bosan dengan pelajaran bahasa inggris, (50\%) siswa masih meragukan kemampuannya untuk berhasil dimasa depan, (32,5\%) siswa tidak percaya diri dengan kemampuannya sendiri. Tujuan penelitian untuk mengetahui hubungan motivasi belajar dan optimisme masa depan dengan prestasi belajar. Desain penelitian metode Depkriptif korelasi, menggunakan pendekatan cross sectional, populasi pada penelitian ini siswa kelas XI di SMKN 9 Kota Tangerang yang berjumlah 260 populasi. Teknik pengambilan sampel menggunakan proposionate stratified random sampling. Sampel penelitian sebanyak 158 responden. Instrumen dalam penelitian ini menggunakan lembar kuesioner dan prestasi belajar menggunakan (PAS) genap 2019-2020. Analisis data yang digunakan yaitu analisis univariat dan analisis bivariat. Analisis bivariat menggunakan uji Chi-Square. Maka disimpulkan hasil penelitian didapatkan siswa dengan motivasi belajar tinggi sebanyak 143 siswa (90,5\%), sedangkan siswa dengan motivasi belajar rendah sebanyak 15 siswa (9,5\%). Optimisme masa depan tinggi sebanyak 147 responden (93,0\%), sedangkan siswa dengan optimisme masa depan rendah sebanyak 11 responden (7,0\%). Prestasi belajar baik sebanyak 87 siswa (55,1\%), sedangkan siswa dengan prestasi belajar kurang baik sebanyak 71 responden (44,9\%). Hasil nilai prestasi belajar Bahasa Inggris terbesar yaitu 100 dan nilai terkecil yaitu 52. Terdapatnya hubungan antara motivasi belajar dengan prestasi belajar dengan nilai $p$ value 0,001. Terdapatnya hubungan antara motivasi belajar dengan prestasi belajar dengan nilai $p$ value 0,001. Terdapatnya hubungan antara optimisme masa depan dengan prestasi belajar dengan nilai p value 0,013.
\end{abstract}

\section{PENDAHULUAN}

Optimisme masa depan akan memberikan harapan yang positif dan dapat meningkatkan motivasi untuk belajar dan berlatih seseorang (Kurniati \& Fakhruddin, 2018). Sikap optimisme yaitu sikap yang harus dimiliki seseorang untuk meraih masa depan tersebut, masa depan merupakan dimana masa 
yang menentukan dan perlu disiapkan dengan baik Adilia dalam (Prayitno \& Ayu, 2017). Salah satunya yaitu dengan meningkatkan pendidikan.

Motivasi belajar memberikan semangat dan gairah belajar sesuai keinginan dan usaha sehingga dapat memperoleh hasil belajar yang lebih baik. Sikap optimis sangat diperlukan dalam bidang pendidikan supaya seseorang menjadi ulet dalam menghadapi tantangan yang sedang dihadapi dikelas saat belajar dan dengan adanya optimisme seseorang menjadi lebih sukses dalam segala hal (Rokhim, 2013). Menurut Education For All Global Monitoring Report 2012 yang dikeluarkan oleh United Nations Educational, Scientific and Cultural Organization (UNESCO), pendidikan Indonesia berada di peringkat ke 64 untuk pendidikan di seluruh dunia dari 120 negara, dan data Education Development Index (EDI) Indonesia, pada 2011 Indonesia berada di peringkat ke 69 dari 127 negara (dwik, 2013).

Prestasi belajar merupakan suatu pencapaian hasil yang diperoleh dari seorang pelajar setelah mengikuti ujian dalam suatu pelajaran tertentu. Prestasi belajar dapat mewujudkan laporan nilai yang dapat tercantum pada buku rapot, atau kartu hasil studi (KHS) Hasil laporan belajar juga dapat diberikan di Penilaian Akhir Semester (PAS).

Belajar bahasa asing tidaklah mudah maka dari itu dapat menguasai Bahasa Inggris sebuah prestasi yang patut dibanggakan. Maka belajar Bahasa Inggris tidak hanya memerlukan kecerdasan otak saja, tetapi juga membutuhkan motivasi dan disiplin diri dalam belajar (Yurni, 2013). Terdapat beberapa penelitian dilakukan oleh Al-tamimi dan shuib (dalam Timo, 2012), (Abdullah, 2006), Wang (2008). Menjelaskan bahwa pentingnya menguasi Bahasa Inggris baik untuk akademis maupun dunia kerja. Berkaitan dengan itu, masa remaja yaitu masa yang tepat untuk merencanakan karir (Sharf, 2010).

Masalah yang terjadi pada siswa SMK/SMA salah satunya yaitu masalah karir. siswa SMA/SMK merasa belum merasa yakin dalam mengambil langkah setelah lulus, menunjukan bahwa $64,25 \%$ pada siswa SMA/SMK dan MA masih belum memiliki keputusan yang jelas mengenai profesi yang akan diambil selanjutnya Hayadin (dalam Islamadina \&Yulianti, 2016).

Tugas perkembangan yang harus dicapai oleh siswa SMK maupun SMA yaitu dengan memiliki wawasan untuk mempersiapkan karir, karena dengan menghadapi Masyarakat Ekonomi Asean (MEA) seharusnya siswa sudah memiliki rencana karir sejak dini. Mempersiapkan diri untuk mengambil keputusan karir menjadi hal yang paling penting terutama bagi siswa SMA dan SMK, dimana terdapat dua pilihan yaitu memilih lanjut kejenjang sekolah yang lebih tinggi atau memilih mencari pekerjaan. Seharusnya siswa memiliki wawasan persiapan untuk menentukan karirnya sejak dini. Dengan bekerja, seseorang merasa lebih diakui, lebih percaya diri, salah satu bagian dari prestasi. Bentuk wujud dari menetukan perencanaan karir, mampu mempersiapkan diri dalam menghadapi persaingan perkembangan pasar global, serta mampu membuktikan bahwa Indonesia mampu dan layak bersaing dalam mempersiapkan pasar global yang di sebut dengan MEA.

Motivasi belajar dan optimisme masa depan merupakan sesuatu yang penting yang harus ada pada diri setiap orang. Prestasi belajar yang baik dapat dimulai dengan optimisme masa depan dan motivasi yang tinggi dalam belajar. Berdasarkan hasil penelitian yang dilakukan oleh Siswoto Hadi Prayitno dan Sylene Meilita Ayu (2017) yang berjudul Hubungan Optimisme Masa Depan dan Motivasi Berprestasi Terhadap Prestasi Belajar Mata Ajar Bahasa Inggris Mahasiswa Semester 1 Prodi DIII Keperawatan Rustida Tahun Ajaran 2016-2017. Yang diambil sempel secara acak sebanyak 51 mahasiswa dengan hasil penelitian didapatkan bahwa yang memiliki optimisme baik sebanyak 45 (88\%) dengan cukup 6 (12\%) sedangkan yang memiliki motivasi belajar baik sebanyak $33(65 \%)$ dan cukup $18(35 \%)$. Maka disimpulkan hasil ini menunjukan bahwa hubungan optimisme masa depan dan motivasi belajar terhadap prestasi belajar sebesar 5,8\%, sedangkan selebihnya prestasi belajar dipengaruhi oleh faktor lain, maka disimpulkan juga bahwa motivasi belajar lebih berpengaruh terhadap prestasi belajar dari pada optimisme masa depan. 
Berdasarkan Studi Pendahuluan yang dilakukan oleh peneliti di SMK Negri 9 Kota Tangerang pada tanggal 03-03-2020 dari jumlah 40 siswa menyatakan bahwa (62,5\%) siswa kesulitan belajar bahasa inggris dan (55\%) siswa bosan dengan pelajaran bahasa inggris, (50\%) siswa masih meragukan kemampuannya untuk berhasil dimasa depan, $(32,5 \%)$ siswa tidak percaya diri dengan kemampuannya sendiri. Penelitian ini bertujuan untuk mengetahui hubungan motivasi belajar dan optimisme masa depan dengan prestasi belajar mata pelajaran Bahasa Inggris.

\section{METODE}

Penelitian ini merupakan jenis penelitian kuantitatif. Desain penelitian ini menggunakan metode deskriptif kolerasi desain penelitian ini digunakan untuk mengetahui hubungan antar variabel, dengan pendekatan cross sectional, yaitu mencari hubungan antara variabel independen dan variabel dependen tanpa harus ada pengukuran ulang atau follow up.

Penelitian ini dilaksanakan pada bulan Juni 2020. Populasi yang ditetepkan pada penelitian ini pada kelas XI di SMK Negeri 9 Kota Tangerang yang berjumlah 260 populasi. Teknik sempel yang digunakan dalam penelitian ini adalah proportionate stratified random sampling dengan menggunakan rumus slovin. Proportionate stratified random sampling adalah apabila populasi memiliki anggota/unsur yang tidak homogen dan berstrata secara proporsional (Sugiyono, 2014). Alat pengumpulan data menggunakan kuesioner dan penilaian akhir semester (PAS) siswa.

Teknik ini digunakan oleh peneliti dalam pengambilan sampel dari populasi dilakukan dengan menggunakan rumus slovin:

$$
n=\frac{\mathrm{N}}{\mathrm{n} \cdot d^{2}+1}
$$

Keterangan :

$\mathrm{n}=$ jumlah sempel

$\mathrm{N}=$ jumlah populasi

$\mathrm{d}=$ batas toleransi kesalahan $5 \%(0,05)$

$n=\frac{\mathrm{N}}{\mathrm{n} \cdot d^{2}+1}$

$n=\frac{260}{260 \cdot 0,05^{2}+1}$

$n=\frac{260}{1,65}$

$n=157,5=158$

Jadi jumlah sampel dalam penelitian ini adalah 158 responden.

\section{HASIL DAN PEMBAHASAN}

\section{HASIL}

Tabel 1 Distribusi Frekuensi Karakteristik Berdasarkan Jenis Kelamin Siswa (n=158)

\begin{tabular}{lll} 
Jenis Kelamin & Frekuensi & Presentase (\%) \\
\hline Laki-laki & 17 & $10,8 \%$ \\
Perempuan & 141 & $89,2 \%$ \\
\hline Total & 158 & $100 \%$ \\
\hline
\end{tabular}


Berdasarkan tabel 1 didapatkan karakteristik jenis kelamin tertinggi yaitu jenis kelamin perempuan sebanyak 141 responden $(89,2 \%)$

Tabel 2. Distribusi Frekuensi Karakteristik Berdasarkan Usia Siswa $(\mathrm{n}=158)$

\begin{tabular}{lll}
\hline Usia & Frekuensi & Persentase \% \\
\hline 16 Tahun & 45 & 28,5 \\
17 Tahun & 110 & 69,6 \\
18 Tahun & 3 & 1,9 \\
\hline Total & 158 & 100 \\
\hline \multicolumn{2}{r}{ Sumber: Hasil Pengisian Kuesioner }
\end{tabular}

Berdasarkan tabel 2 didapatkan karakteristik usia responden tertinggi yaitu usia 17 tahun sebanyak 110 responden $(69,6 \%)$.

1. Analisa Univariat

Tabel 3. Motivasi Belajar Siswa

\begin{tabular}{lll}
\hline $\begin{array}{l}\text { Motivasi } \\
\text { belajar }\end{array}$ & Frekuensi & Presentase (\%) \\
\hline Tinggi & 143 & 90,5 \\
\hline Rendah & 15 & 9,5 \\
\hline Total & 158 & 100 \\
\hline
\end{tabular}

Berdasarkan Tabel 3 diketahui distribusi frekuensi responden dengan motivasi belajar yang tinggi sebanyak 143 responden $(90,5 \%)$.

Tabel 4. Optimisme Masa Depan Siswa SMK Negri 9 Kota Tangerang

\begin{tabular}{lll}
\hline $\begin{array}{l}\text { Optimisme } \\
\text { Masa Depan }\end{array}$ & Frekuensi & Presentase \% \\
\hline Tinggi & 147 & 93,0 \\
Rendah & 11 & 7,0 \\
\hline Total & 158 & 100 \\
\hline
\end{tabular}

Sumber: Hasil Pengisian Kuesioner

Berdasarkan Tabel 4 diketahui distribusi frekuensi responden dengan optimisme masa depan yang tinggi sebanyak 147 responden $(93,0 \%)$.

Tabel 5. Prestasi Belajar Siswa

\begin{tabular}{ccc}
\hline Prestasi belajar & Frekuensi & Presentase $\%$ \\
\hline Baik & 87 & 55,1 \\
Kurang Baik & 71 & 44,9 \\
\hline Total & 158 & 100 \\
\hline
\end{tabular}


Berdasarkan Tabel 5 diketahui distribusi frekuensi responden dengan prestasi belajar yang baik sebanyak 87 responden $(55,1 \%)$.

2. Analisa Bivariat

Tabel 6 Hubungan Motivasi Belajar Dengan Prestasi Belajar

\begin{tabular}{|c|c|c|c|c|c|c|c|}
\hline \multirow{3}{*}{$\begin{array}{l}\text { Motivasi } \\
\text { Belajar }\end{array}$} & \multicolumn{4}{|c|}{ Prestasi Belajar } & \multirow{2}{*}{\multicolumn{2}{|c|}{ Total }} & \multirow{3}{*}{$\begin{array}{l}P \\
\text { Value }\end{array}$} \\
\hline & \multicolumn{2}{|c|}{$\begin{array}{l}\text { Kurang } \\
\text { Baik }\end{array}$} & \multicolumn{2}{|c|}{ Baik } & & & \\
\hline & $\mathrm{N}$ & $\%$ & $\mathrm{~N}$ & $\%$ & $\mathrm{~N}$ & $\%$ & \\
\hline Tinggi & 58 & 40,6 & 85 & 59,4 & 143 & 100 & \\
\hline Rendah & 13 & 86,7 & 2 & 13,3 & 15 & 100 & 0.001 \\
\hline Total & 71 & 44,9 & 87 & 55,1 & 158 & 100 & \\
\hline
\end{tabular}

Sumber: Hasil Pengisian Kuesioner

Berdasarkan uji Chi-Square tabel 6 diketahui p-value 0,001 dan nilai tersebut $<0,05$ yang artinya Ha diterima yang berarti adanya hubungan antara motivasi belajar dengan prestasi belajar.

Tabel 7 hubungan optimisme masa depan dengan prestasi belajar

\begin{tabular}{|c|c|c|c|c|c|c|c|}
\hline \multirow{3}{*}{$\begin{array}{l}\text { Optimisme } \\
\text { Masa } \\
\text { Depan }\end{array}$} & \multicolumn{4}{|c|}{ Prestasi Belajar } & \multirow{2}{*}{\multicolumn{2}{|c|}{ Total }} & \multirow{3}{*}{$\begin{array}{l}P \\
\text { Value }\end{array}$} \\
\hline & \multicolumn{2}{|c|}{$\begin{array}{l}\text { Kurang } \\
\text { Baik }\end{array}$} & \multicolumn{2}{|c|}{ Baik } & & & \\
\hline & $\mathrm{N}$ & $\%$ & $\mathrm{~N}$ & $\%$ & $\mathrm{~N}$ & $\%$ & \\
\hline Tinggi & 62 & 42,2 & 85 & 57,8 & 147 & 100 & \\
\hline Rendah & 9 & 81,8 & 2 & 18,2 & 11 & 100 & 0,013 \\
\hline Total & 71 & 44,9 & 87 & 55,1 & 158 & 100 & \\
\hline
\end{tabular}

Berdasarkan uji Chi-Square tabel 7 diketahui $p$-value 0,013 dan nilai tersebut $<0,05$ yang artinya Ha diterima yang berarti adanya hubungan antara optimisme masa depan dengan prestasi belajar.

\section{PEMBAHASAN}

1. Motivasi belajar

Berdasarkan tabel 3 diketahui hasil studi yang dilakukan oleh peneliti menunjukan bahwa presentase responden yang memiliki motivasi belajar tinggi lebih tinggi yaitu 143 responden $(90,5 \%)$ dari pada responden yang memiliki motivasi belajar rendah yaitu 15 responden $(9,5 \%)$. Motivasi belajar merupakan sesuatu yang dapat memotivasi siswa dan individu untuk belajar. Tanpa adanya motivasi belajar, seorang siswa tidak akan belajar dan pada akhirnya tidak akan mencapai keberhasilan dalam belajarnya (Sani, 2019). Hasil penelitian ini sejalan dengan hasil penelitian (Umboh dkk., 2017) bahwa didapatkan hasil motivasi belajar baik lebih besar dari pada motivasi belajar kurang baik, penelitian ini sejalan dikarenakan responden masih menjalani pendidikan sehingga memiliki motivasi belajar yang tinggi.

\section{Optimisme Masa Depan}

Berdasarkan tabel 4 diketahui hasil studi yang dilakukan oleh peneliti menunjukan bahwa presentase responden memiliki optimisme masa depan tinggi lebih tinggi yaitu 147 responden $(93,0 \%)$ dari pada responden yang memiliki optimisme masa depan rendah yaitu 11 responden (7,0\%). Menurut Adilia dalam (Fawziah dkk., 2019) Optimisme masa depan merupakan harapan yang kuat bahwa segala yang berhubungan dengan kehidupan dapat diselesaikan dengan baik. Hasil penelitian ini sejalan dengan penelitian yang dilakukan oleh (Prayitno \& Ayu, 2017) bahwa mayoritas responden dalam 
penelitian ini memiliki optimisme masa depan baik. Penelitian ini sejalan dikarenakan responden masih berstatus SMK dan memiliki keyakinan kepercayaan diri dengan masa depannya yang ingin diraihnya untuk melanjutkan keperguruan tinggi.

\section{Prestasi Belajar}

Berdasarkan tabel 5 diketahui hasil studi yang dilakukan oleh peneliti menunjukan bahwa presentase responden yang memiliki prestasi belajar baik lebih besar yaitu 87 responden $(55,1 \%)$ dari pada prestasi belajar kurang baik yaitu 71 responden $(44,9 \%)$. Dari hasil penelitian ini diambil dari hasil nilai PAS semester genap, ujian dilakukan melalui online sehingga siswa saat ujian dapat membuka buku (open book) atau dapat bertanya kepada teman maka didapatkan nilai prestasi siswa mayoritas baik. Dalam Kamus Besar Bahasa Indonesia, prestasi merupakan hasil yang telah dicapai (dari yang sudah dilakukan dan dikerjakan).

\section{Hubungan Motivasi Belajar Dengan Prestasi Belajar}

Berdasarkan hasil tabel 6 bahwa dari penelitian pada 158 responden dinyatakan sebanyak 85 responden $(59,4 \%)$ memiliki motivasi belajar tinggi dengan prestasi belajar baik. Penelitian ini menggambarkan bahwa adanya hubungan antara motivasi belajar dengan prestasi belajar dimana $P$ value $\leq 0,05(P=0,001)$ yang artinya terdapat hubungan yang signifikan antara motivasi belajar dengan prestasi belajar dengan tingkat keeratan hubungan sedang. Hasil penelitian ini sejalan dengan penelitian yang dilakukan oleh (Nirmala, 2020) motivasi belajar berpengaruh terhadap prestasi belajar siswa pada pembelajaran Bahasa Inggris. Dan penelitian ini sejalan dengan penelitian yang dilakukan oleh (Putra \& Sumata, 2012) hal ini sesuai dengan teori yang mengatakan bahwa motivasi belajar adalah sesuatu yang dapat memotivasi siswa dan individu untuk belajar. Tanpa adanya motivasi belajar, seorang siswa tidak akan belajar dan pada akhirnya tidak akan mencapai keberhasilan dalam belajarnya (Sani, 2019).

Hal ini diperkuat menurut M.Dalyono dalam (Putra \& Sumata, 2012) minat dan bakat merupakan aspek kejiwaan (psikis). Minat dapat terjadi karena daya tarik dari luar dan juga datang dari hati. Sedangkan motivasi adalah daya penggerak atau pendorong untuk melakukan sesuatu pekerjaan. Kuat lemahnya motivasi belajar seseorang turut mempengaruhi keberhasilan belajarnya.

\section{Hubungan Optimisme Masa Depan Dengan Prestasi Belajar}

Berdasarkan tabel 7 bahwa dari penelitian pada 158 responden dinyatakan sebanyak 85 responden $(57,8 \%)$ yang memiliki optimisme masa depan tinggi dengan prestasi belajar baik. Penelitian ini menggambarkan adanya hubungan antara optimisme masa depan dengan prestasi belajar dimana $P$ value $\leq 0,05(P=0,013)$ yang artinya terdapat hubungan yang signifikan antara optimisme masa depan dengan prestasi belajar dengan tingkat keeratan hubungan sedang.

Penelitian ini sejalan dengan penelitian (Kusmaladewi, 2020) hasil analisis data dapat diketahui bahwa koefisien korelasi sikap optimis dengan prestasi belajar menunjukan bahwa sikap positif mempunyai korelasi positif yang signifikan dengan prestasi belajar.

Hasil temuan ini menunjukan bahwa sikap optimis meliputi, mengejar hari esok lebih baik, unsur penunjang, memiliki sasaran hidup yang jelas, ciptakan opini diri yang kuat, memiliki sikap dan pandangan yang hebat tentang hidup ini, temukan orang yang bisa menginspirasi diri, tinggkatkan keimanan, tambahlah modal hidup, dan buka pintu pencerahan mempunyai pengaruh positif yang signifikan dalam meningkatkan prestasi belajar.

Penelitian ini sejalan dengan penelitian yang dilakukan oleh (Kurniati \& Fakhruddin, 2018) hal ini sesuai dengan teori yang menyatakan bahwa sikap optimis mempengaruhi prestasi belajar siswa. Diperkuat dengan hasil penelitian ini bahwa siswa dengan sikap optimis dan pesimis memiliki perbedaan prestasi belajar yang signifikan. Lebih tepatnya bahwa siswa optimis memperoleh prestasi belajar yang lebih baik dari pada siswa pesimis. Selanjutnya menjadi pekerjaan kita bersama 
bagaimana menumbuhkan sikap optimis dalam sikap individu khususnya siswa untuk dapat meningkatkan hasil belajarnya.

\section{KESIMPULAN DAN SARAN}

Berdasarkan hasil penelitian dan pembahasan tentang Hubungan Motivasi Belajar dan Optimisme Masa Depan Dengan Prestasi Belajar Mata Pelajaran Bahasa Inggris di Kejuruan Kesehatan Smk Negeri 9 Kota Tangerang, maka peneliti mendapat kesimpulan sebagai berikut :

1. Motivasi belajar : berdasarkan hasil penelitian maka didapatkan siswa dengan motivasi belajar tinggi sebanyak 143 siswa (90,5\%), sedangkan siswa dengan motivasi belajar rendah sebanyak 15 siswa $(9,5 \%)$.

2. Optimisme masa depan : berdasarkan hasil penelitian maka didapatkan siswa SMKN 9 Kota Tangerang dengan optimisme masa depan tinggi sebanyak 147 responden $(93,0 \%)$, sedangkan siswa dengan optimisme masa depan rendah sebanyak 11 responden $(7,0 \%)$.

3. Prestasi belajar : berdasarkan hasil penelitian maka didapatkan siswa SMKN 9 Kota Tangerang dengan prestasi belajar baik sebanyak 87 siswa $(55,1 \%)$, sedangkan siswa dengan prestasi belajar kurang baik sebanyak 71 responden $(44,9 \%)$. Hasil nilai prestasi belajar Bahasa Inggris terbesar yaitu 100 dan nilai terkecil yaitu 52 .

4. Terdapatnya hubungan antara motivasi belajar dengan prestasi belajar dengan nilai $\mathrm{p}$ value 0,001 .

5. Terdapatnya hubungan antara optimisme masa depan dengan prestasi belajar dengan nilai $\mathrm{p}$ value 0,013 .

\section{DAFTAR PUSTAKA}

Ardiana, Titin Eka, (2017), Pengaruh Motivasi Kerja Guru Terhadap Kinerja Guru Akuntansi SMK di Kota Madiun, 17(2), 14-23.

Donsu, J. D. (2017). Psikologi Keperawatan Aspek-Aspek Psikologi Konsep Dasar Psikologi Teori Perilaku Manusia.

Dwik. (2013). Faktor-faktor yang Mempengaruhi Prestasi Belajar Mahasiswa Pada Kelompok Mata Kuliah Keahlian Akuntansi. 2(1).

Kurniati, L., \& Fakhruddin, A. U. (2018). Prestasi Belajar Matematika Ditinjau Dari Sikap Optimis Dan Pesimis Siswa Sma. De Fermat: Jurnal Pendidikan Matematika, 1(2), 19-24. https://doi.org/10.36277/defermat.v1i2.22

Prayitno, Siswoto Hadi, \& Ayu, Sylene Meilita. (2017). Hubungan optimisme masa depan dan motivasi berprestasi terhadap prestasi belajar mata ajar bahasa inggris mahasiswa semester 1 prodi di keperawatan rustida tahun ajaran 2016-2017. 13(2), 80-95.

Rokhim, A. R. (2013). Hubungan Antara Motivasi Belajar dengan Optimisme Masa Depan Pada Mahasiswa Program Twinning Di Universitas Muhammadiyah Surakarta (Doctoral dissertation, Universitas Muhammadiyah Surakarta).

Sari, \& Kadri. (2018). Pengaruh Model Group Investigation Terhadap Pengetahuan Konseptual Pada Materi Pokok Suhu Dan Kalor Di Kelas XI Smk Muhammadiyah 8 Medan. 7(2), 77 83.

Islamadina, E. F. \& Yulianti, A. (2016). Persepsi terhadap dukungan orangtua dan kesulitan pengambilan keputusan karir pada remaja. Jurnal Psikologi, 12(1), 33-38.

Sugiyono. (2014). Metode Penelitian Kuantitatif Kualitatif dan R\&D. Bandung: Alfabeta

UNESCO. (2012). Monitoring and Evaluation Guidance For School Health : Eigth indicators to support FRESH. UNESCO-WHO 
Journal of Educational Review and Research

Vol. 4 No. 1, July 2021. Page: $6-13$

e-ISSN: 2597-9760, p-ISSN: 2597-9752

Yurni. (2013). Hubungan antara Regulasi Diri dalam Belajar dengan Prestasi Belajar Mahasiswa FKIP Jurusan Pendidikan Bahasa Inggris UNBARI. Jurnal Ilmiah Universitas Batanghari Jambi, 13(4), 19-23 